\title{
A költségvetési politika és a gazdaság ciklikus pozíciójának kapcsolata*
}

\author{
Molnár György - Soós Gábor Dániel - Világi Balázs
}

A 2007-2008-as pénzügyi válság és az azt követő mély és elhúzódó recesszió során elötérbe került az a kérdés, hogy a költségvetési politika alkalmazható-e a gazdaság élénkitésére, mivel a monetáris politika hagyományos eszköztára hatástalanná vált. Ebböl adódóan a kapcsolódó kutatások is új lendületet kaptak. Írásunk célja az új kutatási eredmények ismertetése, amelyek föként arra fókuszálnak, hogy alkalmazható-e a költségvetési politika a gazdasági ciklusok befolyásolására. Bár továbbra is sok a vita, egyre több elméleti modell és empirikus eredmény támasztja alá azt a véleményt, miszerint a költségvetési politika hatásai nem állandók, hanem a gazdaság ciklikus pozíciójától függenek: elhúzódó mély recessziókban, különösen likviditási csapda esetén a költségvetési kiadások multiplikátora nagy, míg fellendülések idején relative kicsi.

Journal of Economic Literature (JEL) kódok: E62, E52, E21, E12

Kulcsszavak: költségvetési politika, kiadási multiplikátor, gazdasági ciklusok, likviditási csapda, adósságkorlátos háztartások

\section{Bevezetés}

Az elmúlt nyolcvan évben jelentős mértékben változott a közgazdaságtan álláspontja a költségvetési politika alkalmazhatóságáról. Az 1930-as években Keynes munkássága nyomán uralkodóvá vált az a nézet, hogy a költségvetési politika alkalmas a recessziókban a gazdaság élénkítésére, illetve általánosabban a gazdasági ciklusok befolyásolására. Az 1970-es években ennek gyökeresen ellentmondó nézeteket fogalmazott meg az újklasszikus közgazdaságtan, és a költségvetési politikával szembeni kételyek fokozatosan átformálták a közgazdasági gondolkodást.

A 2007-2008-as pénzügyi válság és az azt követő mély és elhúzódó recesszió során viszont ismét előtérbe került a költségvetési politika, mivel a monetáris politika hagyományos eszköztára beleütközött a korlátaiba. Ennek hatására a kapcsolódó

* Jelen cikk a szerző nézeteit tartalmazza, és nem feltétlenül tükrözi a Magyar Nemzeti Bank hivatalos álláspontját.

Molnár György a Magyar Nemzeti Bank elemzője volt a tanulmány írásakor.

E-mail: gyorgy.molnar@ogresearch.com

Soós Gábor Dániel a Magyar Nemzeti Bank vezetö közgazdasági elemzője. E-mail: soosg@mnb.hu

Világi Balázs a Magyar Nemzeti Bank föosztályvezetője. E-mail: vilagib@mnb.hu

A magyar nyelvű kézirat első változata 2016. december 20-án érkezett szerkesztőségünkbe.

DOI: http://doi.org/10.25201/HSZ.16.4.5885 
elméleti és empirikus kutatások is új lendületet kaptak, írásunk célja pedig az, hogy bemutassuk ezeket az új kutatási eredményeket.

Bár továbbra is sok a vita a költségvetési politika alkalmazhatóságáról, egyre általánosabb az a nézet, hogy a költségvetési politika hatásai nem állandók, hanem a gazdaság ciklikus pozíciójától függenek. A fiskális kiadások recessziókban nagyobb, fellendülések idején kisebb mértékben képesek befolyásolni a reál-GDP alakulását.

Mivel írásunk döntően az új kutatások ismertetésére fókuszál, azok pedig főként azt vizsgálják, hogy milyen körülmények esetén alkalmas a fiskális politika a konjunktúraciklusok befolyásolására, ezért ebben a tanulmányban nem foglalkozunk a fiskális politikának a hosszú távú növekedésre gyakorolt hatásával, illetve csak érintőlegesen tárgyaljuk az államadósság fentarthatóságának problémáját. Nem tagadjuk ezeknek a problémáknak a fontosságát, de a terjedelmi korlátokat is figyelembe véve szándékosan szúkítettük az írásunk tárgyát, és döntően azokra az új kutatásokra koncentrálunk, amik egyelőre nem találtak utat a szélesebb szakmai közvéleményhez.

A tanulmány felépítése a következő. A 2. szakaszban áttekintjük, hogy miként változott a fiskális politika elmélete Keynes óta, valamint azt, hogy mi a közgazdaságtan jelenlegi álláspontja. A 3. szakaszban megvizsgáljuk, hogy a fiskális politika hatásainak mérése milyen módszertani kérdéseket vet fel, és ismertetjük az empirikus vizsgálatok eredményeit. A 4. szakasz mindezen eredmények gazdaságpolitikai implikációit tárgyalja, az 5. szakasz pedig a következtetéseinket tartalmazza.

\section{Elmélet}

A tanulmány tárgya annak a vizsgálata, hogy a költségvetési - vagy más néven fiskális - politika képes-e befolyásolni a gazdasági ciklusok alakulását. Ezért nem foglalkozunk olyan a költségvetési politikához kapcsolódó egyéb kérdésekkel, mint az állam szerepe a közjavak létrehozásában, vagy hogy az állami beruházások miként befolyásolják a gazdaság hosszú távú növekedési potenciálját.

Hogy milyen hatásfokkal képes a költségvetési politika befolyásolni a gazdaság ciklusokat, azt az úgynevezett kiadási multiplikátor nagysága jellemzi. A kiadási multiplikátor azt méri, hogy a reál kormányzati kiadások egységnyi növelése hány egységgel növeli a reál-GDP-t.

Ha a multiplikátor értéke 0 , akkor a kormányzati kiadások növekedésének minden egysége ugyanannyival csökkenti a magánfogyasztást vagy -beruházást. Másként szólva a kormányzati kiadások magánkiadásokat szorítanak ki. Extrém esetben a multiplikátor lehet negatív is, ilyenkor egységnyi kormányzati kiadás több mint egységnyi magánkiadást szorít ki. Ezekben az esetekben a fiskális költekezés nem 
növeli, sőt akár csökkenti a reál-GDP-t, tehát ilyenkor a költségvetési politika teljesen hatástalan.

Ha a kiadási multiplikátor 0 és 1 közé esik, akkor a kormányzati kiadások csak részlegesen szorítanak ki magánkiadásokat, a kormányzati kiadások egységnyi növelése egységnyinél kisebb mértékben csökkenti a magánfogyasztást és -beruházást. Ebben az esetben már lehetséges fiskális költekezéssel növelni a reál-GDP-t. Ugyanakkor ebben az esetben a GDP növelésével párhuzamosan csökkenhet a társadalmi jólét, ha a kormányzati költekezés szignifikáns mértékben szorít ki magánfogyasztást, vagy lehet, hogy csökkenti a hosszú távú növekedést, ha fontos magánberuházásokat szorít ki. Tehát ilyen esetben nagy körültekintést igényel a fiskális politika gazdaságélénkítésre való használata, gondosan kell mérlegelni a hasznokat és költségeket.

Ha a multiplikátor értéke 1, akkor már egyáltalán nem szorít ki magánkiadásokat a fiskális politika, ha pedig 1-nél nagyobb, akkor a kormányzati kiadások nemhogy nem szorítanak ki magánkiadásokat, hanem addicionális magánjövedelmeket generálnak. Ezekben az esetekben már egyértelműen érdemes a fiskális politikát a gazdaság élénkítésére használni. A továbbiakban azzal a kifejezéssel, hogy a költségvetési politika hatékony, arra az esetre fogunk utalni, amikor a kiadási multiplikátor értéke nagyobb, mint 1.

Írásunk elsősorban a kiadási multiplikátor nagyságára fókuszál, mivel a válság után a fő vitatéma az volt, hogy a kormányzati kiadások növelése képes-e a recessziót enyhíteni. A kiadási multiplikátor mellett az irodalom részletesen tárgyalja a különböző adók negatív multiplikátorhatását. Mi ezt a kérdést csak részlegesen vizsgáljuk, elsősorban abban a kontextusban, hogy a kormányzati kiadások különböző finanszírozási formái milyen mértékben gyengíthetik a kiadási multiplikátor hatását.

\subsection{A fiskális politika keynesi elmélete}

A keynesi elmélet ma már a makroökonómia tankönyvek anyagának szerves része. Például a keynesi elméleten alapuló IS-LM görbék rendszerét és annak a költségvetési politikára vonatkozó következtetéseit alaposan tárgyalja Benczes és Kutasi (2010) könyvének 2. fejezete. Éppen ezért az alábbi áttekintéssel nem szándékozunk új ismereteket átadni, a célunk vele az, hogy a későbbi szakaszokban tárgyalt új elméletek ismertetését előkészítsük. A most kövező szakasznak nem az a célja, hogy az IS-LM görbéket formálisan levezessük, hanem, hogy világossá tegyük, hogy a keynesi elméletnek melyek azok a kulcsfeltevései, amelyekből következnek a költségvetési politikára vonatkozó eredményei.

Az 1930-as éveket megelőzően általános volt az a vélekedés, hogy a fiskális politika nem hat a GDP-re, mivel a kormányzati költekezés magánkiadásokat szorít ki. ${ }^{1}$

\footnotetext{
${ }^{1}$ Ugyanakkor a klasszikus elmélet nem utasította el teljesen a deficitfelhalmozást, rendkívüli esetekben, például háborúk idején helyénvalónak találta.
} 
Az 1929-1933-as válság után Keynes munkássága változtatta meg a többségi álláspontot ezzel kapcsolatban.

Keynes szerint egységnyi kormányzati reálkiadás egységnyinél nagyobb mértékben növeli a reál-GDP-t. Keynes gondolatmenete jól ismert a bevezető makroökonómia tankönyvekből. Egységnyi kormányzati kiadás² első körben egységnyivel növeli a GDP-t, de itt nem ér véget a folyamat. A GDP növekedése miatt nő a háztartások jövedelme, és mivel Keynes szerint a fogyasztás szorosan együtt mozog a folyó jövedelemmel, ezért a háztartások fogyasztása és ebből adódóan az aggregált kereslet is növekszik, ami tovább növeli a GDP-t, aminek hatására tovább nő a háztartások fogyasztása, és így tovább (lásd az 1. ábrát).

A háztartások folyó jövedelme és a fogyasztás közötti kapcsolatot a fogyasztási határhajlandóság (marginal propensity to consume) ragadja meg. Ez azt fejezi ki, hogy egységnyi folyó jövedelem hány egységgel növeli a fogyasztást. Ha c-vel jelöljük a fogyasztási határhajlandóságot, $0<c<1$, akkor Keynes szerint egységnyi kormányzati költekezés $1 /(1-c)$-vel növeli a GDP-t. Ez utóbbi formulát hívjuk keynesi kiadási multiplikátornak, mivel c pozitív és 1-nél kisebb, a keynesi multiplikátor 1-nél nagyobb, továbbá minél nagyobb a fogyasztási határhajlandóság, annál nagyobb a multiplikátor értéke.

A keynesi elméletben kulcsszerepet játszik a folyó jövedelem és a fogyasztás együttmozgása, de egyéb feltételekre is szükség van ahhoz, hogy bizonyítható legyen, hogy a költségvetési politika hatékonyan képes növelni a gazdasági aktivitást.

A keynesi elmélet lényegében az aggregált kereslet elmélete, és feltételezi, hogy az aggregált kereslet alakulása határozza meg a GDP-t. Azaz a növekvő aggregált keresletre a kínálat nem az árak emelkedésével, hanem mennyiségi expanzióval reagál. A makroökonómia nyelvén kifejezve, az aggregált kínálati görbe vízszintes, ezért az aggregált keresleti görbe eltolódása hatására az új egyensúlyban a kibocsátás magasabb lesz, az árszínvonal viszont változatlan marad.

\footnotetext{
${ }^{2}$ Hogy a gondolatmenet lényege könnyebben érthető legyen, követve a makroökonómiai irodalomban megszokott egyszerúsítést, a cikkben végig feltételezzük, hogy a kormányzati kiadások a kormányzati fogyasztást és kormányzati beruházásokat tartalmazza. Eltekintünk a lakossági és vállalati transzferektől, ami a gyakorlatban szintén része a kormányzati költekezésnek.
} 


\section{1. ábra \\ A kiadási multiplikátor és a folyó jövedelem}

Többlet-

jövedelem a

háztartásoknak
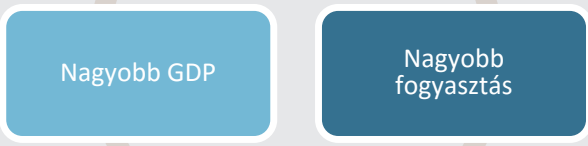

Nagyobb

aggregált kereslet

Mivel a keynesi elmélet az 1930-as évek nagy válságának a hatására született, természetes feltételezés volt, hogy a kínálati alkalmazkodás döntően mennyiségi, mivel a korszak depressziós gazdaságára valóban az volt a jellemző, hogy a nagy kihasználatlan kapacitások mellett az árak és a bérek merevek voltak.

A kínálati feltevések mellett a költségvetési kiadások finanszírozási módjára tett feltevések is befolyásolják a multiplikátor nagyságát. A kiadási multiplikátor nagysága nem független attól, hogy milyen módon finanszírozzák a kiadásokat. A multiplikátor csak akkor éri el a maximális $1 /(1-c)$ értékét, ha a költségvetési expanziót adósságból finanszírozza a kormányzat. Ha a kiadásokat részben adóból finanszírozzák, az csökkenti a multiplikátor nagyságát, hiszen kisebb lesz a háztartások rendelkezésre álló jövedelme, ezáltal kisebb a fogyasztás, valamint az aggregált kereslet növekedése. Belátható, hogy ha a költségvetési expanziót teljes mértékben adókból finanszírozzák, akkor a multiplikátor nagysága 1-re csökken. A 2. ábra foglalja össze, hogy a keynesi kiadási multiplikátor elmélet milyen tényezőkön alapul.

Végezetül érdemes tisztázni egy gyakori, a keynesi elmélettel kapcsolatos félreértést. Az elmélet szerint a multiplikátor nagysága független attól, hogy a költségvetési kiadásokat haszontalan dolgokra költi a kormányzat, vagy hasznos, például infrastrukturális beruházásokra vagy a humántőke fejlesztésére. A keynesi elmélet nem a gazdaság hosszú távú növekedését meghatározó tényezőket akarta magyarázni, hanem arra kívánt megoldást találni, hogy miként lehet egy olyan válságból kilábalni, amikor elégtelen nagyságú az aggregált kereslet, és a monetáris politika már nem képes élénkíteni a gazdaságot. A keynesi elmélet kulcsa az, hogy a kormányzati költekezés addicionális magánjövedelmeket generál, ebből a szempontból mindegy, hogy a magánkeresletet indukáló kezdeti kormányzati kiadások mire irányulnak. 
Természetesen a gazdaság hosszú távú növekedésére hatással lehet, hogy a kormányzati kiadások mire irányulnak, hiszen a hatékony állami kiadások növelhetik a jövőbeli potenciális kibocsátást. De a keynesi elmélet ezt a kérdést nem vizsgálja, a vizsgálatának a tárgya a költségvetési politika rövid távú hatásai.

\section{2. ábra}

A keynesi kiadási multiplikátor

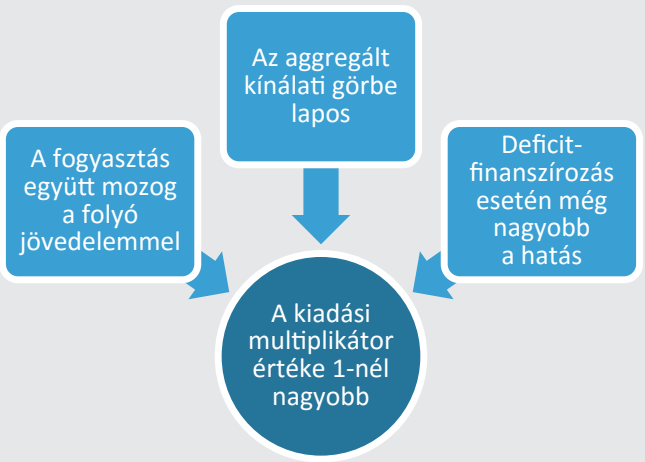

\subsection{A keynesi elmélet kritikája}

Amint azt az előző szakaszban tárgyaltuk, a keynesi elmélet következtetései szempontjából alapvető az a feltevés, hogy a fogyasztás és a folyó jövedelmek között szoros kapcsolat áll fenn. Keynes fogyasztási elméletét azonban a későbbiekben komoly kritikák érték, elsősorban Milton Friedman (1957) permanes jövedelem elmélete és Franco Modigliani (1966) életciklus-hipotézise állította komoly kihívások elé. Mindkét szerző empirikusan és elméletileg is alátámasztotta, hogy a háztartások fogyasztási döntéseiknél nemcsak a folyó jövedelmük alakulását, hanem a jövedelmeik hosszabb távú alakulását is figyelembe veszik.

Másként fogalmazva, a háztartások simítják a fogyasztásukat, azaz a jövedelmük ingadozását nem követi teljes mértékben a fogyasztás ingadozása. Ezt az adatok is alátámasztják, az aggregált fogyasztás ingadozása kisebb, mint a GDP ingadozása. A fogyasztás simítása konkrétan azt jelenti, hogy ha a háztartásoknak átmenetileg alacsonyabb lesz a jövedelmük, akkor csökkentik a megtakarításaikat, és megpróbálják a fogyasztásuk szintjét fenntartani. Ha pedig átmenetileg megnő a jövedelmük, akkor a jövedelemnövekményt nem költik teljes egészében folyó fogyasztásra, hanem egy részét megtakarítják, hogy a jövőbeli fogyasztásuk is növekedhessen.

A fentieknek az a következménye, hogy a fogyasztási határhajlandóság alacsonyabb annál, mint Keynes feltételezte. Amint azt tárgyaltuk, a keynesi kiadás multiplikátor 
nagysága $1 /(1-c)$, ha a fogyasztási határhajlandóság, azaz $c$ alacsony, akkor a multiplikátor értéke is 1-hez közeli lesz.

A keynesi fogyasztási függvény elvetésének további következményei is vannak. A keynesi fogyasztási elmélet alapvetően statikus, a folyó fogyasztást csak a folyó jövedelem befolyásolja. Ezzel szemben a későbbi fogyasztási modellek dinamikusak, a háztartás egy hosszabb időszakot figyelembe véve alakítja ki optimális fogyasztási pályáját. Ebből adódóan a fogyasztási döntésekre a jövedelem mellett a reálkamatlábnak is jelentős befolyása van. Mivel a monetáris politika képes befolyásolni a reálkamatot, ezért a fogyasztásra és az aggregált keresletre is jelentős hatása van. Ebből adódóan a monetáris politika képes semlegesíteni a költségvetési politika hatását. Tegyük fel, hogy a jegybank döntései leírhatók a következő kamatszabály segítségével: az infláció, illetve a reál-GDP növekedése esetén a jegybank kamatot emel. A költségvetési kiadások növekedése esetén nő az infláció és a kibocsátás, ebből adódóan a jegybank kamatot emel, ami a reálkamatláb emelkedését vonja maga után, ennek hatására pedig csökken a fogyasztás és az aggregált kereslet, aminek következményeként csökken a fiskális politika hatékonysága, bizonyos feltételek mellett 1-nél kisebb lesz a kiadási multiplikátor.

Az 1970-es évektől még radikálisabb kritika érte a keynesi elméletet a Robert Lucas nevével fémjelezhető újklasszikus iskola részéről, ami kétségbe vonta a kínálat viselkedéséről kialakított keynesi vélekedést is. Szerintük az árak és bérek rugalmasan reagálnak az aggregált kereslet változásaira, ezért a kínálat alkalmazkodása alapvetően nem mennyiségi. Véleményük szerint az aggregált kínálati görbe alapvetően függőleges, a függőlegestől csak átmenetileg tér el akkor, ha előre nem látott meglepetés éri a vállalatokat (Lucas 1973; Sargent - Wallace 1975). Ennek az a következménye, hogy ha egy elöre látott költségvetési expanzió hatására eltolódik az aggregált keresleti görbe, akkor annak nincs mennyiségi hatása, a reál-GDP nem változik, ezzel szemben az árszínvonal nőni fog. Azaz ilyen esetben a kiadási multiplikátor értéke nulla. Ha a költségvetési expanzió meglepetésként éri a vállalatokat, akkor átmenetileg mennyiségileg is reagál a kínálat, de a GDP növekedése ilyenkor is jóval kisebb annál, mint amit Keynes feltételezett.

Az újklasszikus elméletnek az aggregált kínálat viselkedésére vonatkozó nézetei formálisan az újklasszikus Phillips-görbe segítségével foglalható össze, amit például Benczes és Kutasi (2010) 4. fejezete tárgyal.

Az újklasszikus kritika másik fontos eleme a ricardói ekvivalencia volt, amit Barro (1977) fogalmazott meg először. Eszerint, ha a költségvetési költekezést deficitből finanszírozzák, annak pontosan ugyanakkora hatása van, mint az adófinanszírozásnak. Az ezt alátámasztó érvelés a következőképpen hangzik: A permanens jövedelem elmélet szerint a háztartások fogyasztási döntéseit nem a folyó, hanem az úgynevezett életpálya-jövedelem jelenértéke határozza meg. Ha a fogyasztók 
kellően racionálisak, akkor azt is pontosan értik, hogy a jelenbeli költségvetési deficit magasabb adókat implikál a jövőben, hiszen a kormányzat adósságát is vissza kell fizetni a jövőben. Vagyis, ha a költségvetési expanziót nem a jelenlegi adókból finanszírozzák, akkor azt a jövőbeli adókból fogják. Belátható, hogy a jövőbeli adóemelés jelenértéke éppen akkora, mint a jelenbeli adóemelés nagysága, ezért mindkét esetben ugyanannyival csökken az életpálya-jövedelem jelenértéke, és ebből adódóan ugyanannyival csökken a folyó fogyasztás is.

Fontos hangsúlyozni, hogy a ricardói ekvivalenciának az a következménye, hogy a kiadási multiplikátor nagysága független a költségvetési kiadások finanszírozásának módjától, ebből azonban még nem következik, hogy a kiadási multiplikátor értéke 1-nél kisebb legyen. A ricardói ekvivalencia csak annyit állít, hogy bármekkora is a multiplikátor nagysága abban az esetben, ha a kiadásokat teljes mértékben adókból finanszírozzák, ez az érték nem növelhető tovább. Tehát a ricardói ekvivalencia csak akkor támasztja alá azt, hogy a költségvetési politika nem hatékony, ha az adóból finanszírozott kiadások multiplikátora 1-nél kisebb. A ricardói ekvivalencia hiányában ilyenkor lehet azzal érvelni, hogy deficit-finanszírozás esetén ez azt érték akár 1-nél nagyobb is lehet, de ha elfogadjuk a ricardói ekvivalenciát, akkor ez nem következhet be. Tehát a ricardói ekvivalencia csak akkor alkalmas a költségvetési politikával szembeni szkeptikus álláspont alátámasztására, ha azt kiegészítjük egyéb, például a kínálat viselkedésére vonatkozó érvekkel.

A fenti kritikákat a 3. ábra foglalja össze. Ezek alapvetően arra irányultak, hogy bizonyítsák, a költségvetési politika nem hatékony, egységnyi költségvetési kiadás egységnyinél kisebb mértékben növeli a reál-GDP-t, mert magánkiadásokat szorít ki. De léteznek a fiskális politika gyakorlati implementálásához kapcsolódó ellenérvek is, az alábbiakban ezeket tekintjük át.

Az egyik gyakori ellenérv az, hogy a monetáris politika segítségével sokkal hatékonyabban lehet a gazdaság ingadozásait simítani, mint költségvetési politikával. Eszerint míg a monetáris politika gyorsan és hatékonyan tud reagálni a gazdaság változásaira, egy jegybank döntéshozó testülete bármikor összeülhet, és néhány óra alatt meghozhatja az irányadó kamatra vonatkozó döntését, addig a költségvetési automatikus stabilizátorokat ${ }^{3}$ kiegészítő, diszkrecionális költségvetési politika egy lassú és nehézkes törvényhozási folyamat eredménye, ezért csak nagy késésekkel tud reagálni a gazdasági fejleményekre.

Továbbá nemcsak az tart sokáig, míg egy döntést meghoznak, hanem az is hosszú idő, ami a döntés és költségvetési projekt megvalósulása között eltelik. Tehát előfordulhat, hogy a költségvetési politika hatását csak több év késéssel tudja kifejteni, ezzel szemben a monetáris politika esetében egy kamatdöntést követően lényegé-

\footnotetext{
${ }^{3}$ Automatikus stabilizátoroknak azt nevezzük, amikor a költségvetési egyenleg automatikusan megváltozik akkor, ha a gazdasági konjunktúra új fázisba lép.
} 
ben azonnal bevezethetik az új kamatokat. Mindez azzal a következménnyel járhat, hogy ha egy recesszióban a költségvetési politika segítségével próbálják élénkíteni a gazdaságot, akkor mire az kifejti a hatását, már vége a recessziónak. Ezt különösen fontos problémának tartották a válság előtti két évtizedben, az úgynevezett nagy moderáció időszakában, amikor a fejlett gazdaságok esetében a konjunktúraciklusok ingadozásának mélysége és a recessziók hossza jelentős mértékben csökkent. ${ }^{4}$

\section{3. ábra \\ A keynesi kiadási multiplikátor kritikája}

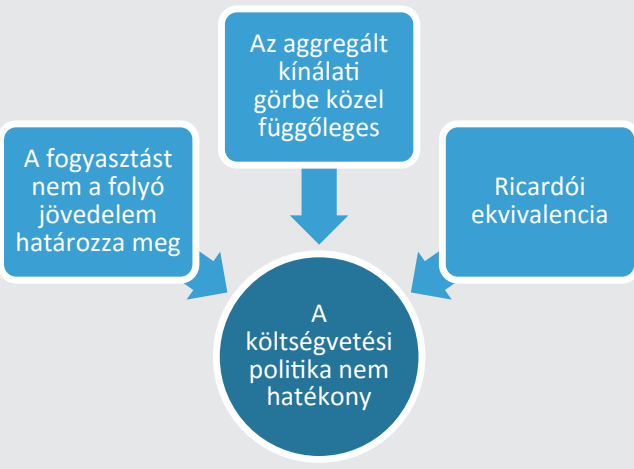

\subsection{A válság utáni nézetek}

Az eddigiekben összefoglaltuk, hogy a válság előtt hogyan vélekedett a közgazdaságtan a fiskális politika hatékonyságáról. Ezek a szélesebb szakmai közvélemény előtt is ismert eredmények. Az áttekintéssel az volt a célunk, hogy előkészítsük az új kutatási eredmények tárgyalását, és azokat kontextusba helyezzük. Ezek a kutatások jelentős részben a modern makroökonómia sztochasztikus dinamikus eszköztárán alapulnak, és az ebből adódó technikai korlátok miatt még nem találtak utat a bevezető tankönyvekbe, illetve a szélesebb szakmai közvéleményhez. A továbbiakban kísérletet teszünk ezeknek az eredményeknek a közérthető ismertetésére.

A 2007-2008-as válság és az azt követő recesszió arra kényszerítette a szakmát, hogy átértékelje a fiskális politika szerepére vonatkozó nézeteket. Ennek eredményeként ma a szakma jóval differenciáltabban gondolkozik a költségvetési politika alkalmazási lehetőségéről, mint megelőzően.

\footnotetext{
${ }^{4}$ Milton Friedmanig vezethető vissza az a gondolat, hogy többek között a késleltetett hatások miatt nem érdemes diszkrecionális gazdaságpolitikát folytatni.
} 
Nem arról van szó, hogy az inga az egyik szélsőség irányából visszalendült a másik irányba. Az eredeti formájában ma már nem elfogadható a keynesi elmélet, de világossá vált, hogy annak sok eleme újra releváns lehet, bizonyos feltételek mellett. Világossá vált, hogy a költségvetési politika alkalmazhatósága nem egy időtől független adottság, hanem a gazdaság állapotának, a gazdasági konjunktúrának a függvénye. Ebben a szakaszban ezt az újragondolási folyamatot tekintjük át.

Először azt vizsgáljuk, hogyan változott meg a szakma véleménye a költségvetési politika praktikus alkalmazhatóságáról. Egyrészt bebizonyosodott, hogy a monetáris politika nem minden helyzetben hatékony. Már Keynes felismerte az 1930-as években, hogy nagy recesszióban és alacsony kamatkörnyezetben a monetáris politika hatástalanná válik, ezt nevezte likviditási csapdának. A likviditási csapda ritka jelenség, ezért nem is vette komolyan a szakma, bár Japán hosszú recessziója az 1990-es években figyelmeztető jel lehetett volna. A válság után azonban mind az euroövezet, mind az Egyesült Államok likviditási csapdába került, a gazdaság megfelelő élénkítéséhez szükséges reálkamatláb (a reálkamatláb természetes rátája) negatívvá vált, a monetáris politika viszont nem volt képes ezt a negatív reálkamatláb szintet elérni, hiszen alacsony infláció mellett ehhez szignifikánsan negatív nominális kamatlábra lett volna szükség, ami nem lehetséges. Ugyan nemkonvencionális eszközökkel lehetséges volt valamennyire élénkíteni a gazdaságot, de alapvetően a monetáris politika elérte lehetőségei határát. Ilyen helyzetben természetesen merült fel a fiskális politika mint alternatív eszköz alkalmazása.

Az 1980-as évektől a gazdaság ingadozások mértéke minden addiginál kisebbé vált, amint már említettük, ezt az időszakot hívja az irodalom nagy moderációnak. Ezzel szemben az 1930-as évek nagy válsága óta nem volt olyan mély és hosszan tartó recesszió a fejlett világban, mint a 2008-at követő. A 4. ábra négy fejlett gazdaság recesszióját ábrázolja. Amint az ábrán látható a válság utáni gazdasági visszaesés mind a négy országban tartós és mély volt. Ráadásul a válság utáni helyzet a hiszterézis fogalmával jellemezhető: az ábrázolt gazdaságok a válság előttinél alacsonyabb trendvonal mentén növekednek, vagy még ettől is elmaradnak ${ }^{5}$. Mindezek alapján elmondható, hogy nem érvényes az a nagy moderáció időszakában megfogalmazott érv, hogy a recessziók rövidsége miatt nem érdemes költségvetési politikát alkalmazni a ciklusok simítására.

\footnotetext{
${ }^{5}$ A hiszterézisről lásd Blanchard és szerzőtársai (2014) tanulmányát.
} 


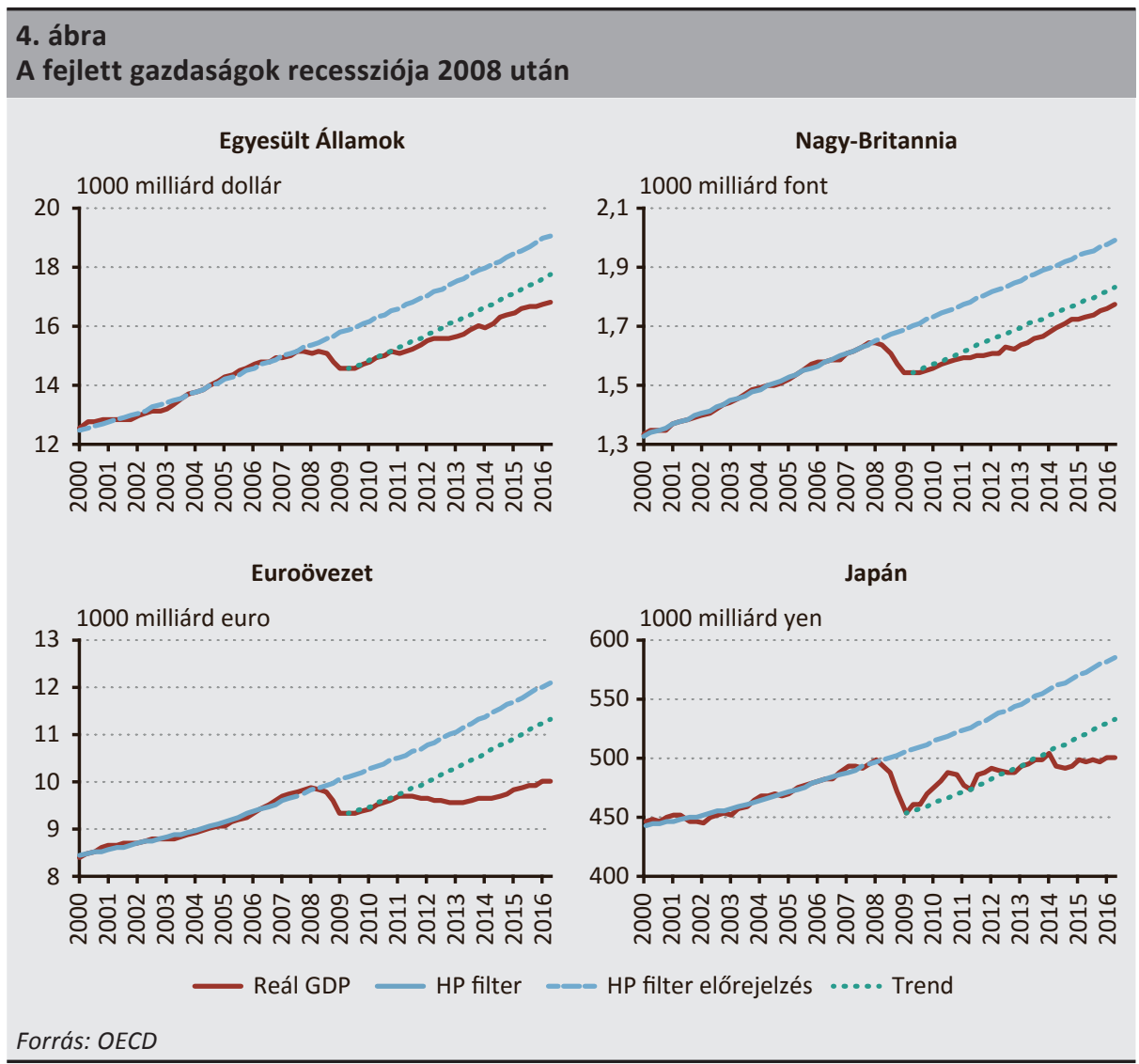

Az újklasszikus közgazdaságtannak az aggregált kínálati görbére vonatkozó extrém nézeteinek az átértékelése már jóval a válság előtt elkezdődött. Ezt a folyamatot nem a költségvetési politikáról szóló gondolkodás motiválta, hanem az, hogy az újklasszikus makroökonómia szerint a monetáris politikának nincs hatása a reálgazdaságra, ami ellentmondott mind a tudományos kutatások empirikus eredményeinek, mind a gyakorlati jegybankárok tapasztalatainak.

Az 1990-es évektől a makroökonómiai modellek többségében a kínálat viselkedését az új-keynesi Phillips-görbe segítségével írták le, ennek formális levezetése megtalálható Galí (2008) haladó szintű tankönyvében. Az új-keynesi Phillips-görbe csak a nevében kapcsolódik az előző szakaszban tárgyalt újklasszikus Phillips-görbéhez, teljesen más koncepción alapul. Míg az újklasszikus elméletben a kínálat átmeneti rugalmatlanságai a gazdasági szereplők tökéletlen információira vezethetők vissza, addig az új-keynesi Phillips-görbe Calvo (1983) ragadós árak elméletén alapul. ${ }^{6}$

\footnotetext{
${ }^{6}$ Az újklasszikus és az új-keynesi Phillips-görbéről lásd még Szentmihályi és Világi (2015) tanulmányát.
} 
Az új-keynesi Phillips-görbe segítségével jóval kiegyensúlyozottabb módon írható le a kínálat viselkedése, mint azt az újklasszikus iskola teszi. A ragadós árak feltevése következményeként a kereslet növekedésére a vállalatok egy része az árak emelésével reagál, egy másik része pedig mennyiségi expanzióval. Ennek eredményeként az aggregált kínálati görbe emelkedő, nem vízszintes, mint az eredeti keynesi elméletben és nem függőleges, mint az újklasszikus modellekben. Tehát ha egy költségvetési expanzió hatására eltolódik az aggregált kereslet, akkor annak hatására nőni fog mind az árszínvonal, mind a reál-GDP. A mennyiségi elmozdulás annál nagyobb, minél laposabb a görbe. Az eredeti keynesi megközelítéshez képest a GDP-hatás és a kiadási multiplikátor kisebb lesz, de ha az új-keynesi Phillips-görbe meredeksége nem túl nagy, akkor a kiadási multiplikátor 1-nél nagyobb. Ez a következtetés gyökeresen eltér az újklasszikus iskola állításaitól, ami szerint csak a meglepetésszerü költségvetési expanziónak van reálhatása, de az is csak átmeneti és elhanyagolható nagyságú.

Az előzőekből nyilvánvaló, hogy a kiadási multiplikátor annál nagyobb, minél kisebb az új-keynesi Phillips-görbe meredeksége. Recessziókban kihasználatlan kapacitások esetén csökken az áralkalmazkodás jelentősége, ebből adódóan pedig a görbe meredeksége is. Mindez azt támasztja alá, hogy válságokban, ha egy költségvetési expanzió hatékonyan képes megnövelni az aggregált keresletet, akkor annak jelentős része a GDP növekedésében fog lecsapódni, az inflációs hatása pedig minimális lesz.

Kiterjedt empirikus irodalom foglalkozott továbbá azzal a folyamattal, hogy az elmúlt évtizedekben, már jóval a válság előtt a Phillips-görbe meredeksége szignifikánsan csökkent, amint azt Szentmihályi és Világi (2015) összefoglaló tanulmánya tárgyalja. A Phillips-görbe ellaposodása már jóval válság előtt elkezdődött, de a válság során a jelenség felerősödött, a bérek lefelé merev volta és a kihasználatlan kapacitások miatt.

Amint az előző szakaszban tárgyaltuk, ha a fogyasztást nemcsak a jövedelem, hanem a reálkamatláb is befolyásolja, akkor a költségvetési expanziót jelentős mértékben semlegesíti. Viszont ha egy válság során a gazdaság likviditási csapdába kerül, akkor a monetáris politika eléri a nominális kamatlábak zéró korlátját, és a jegybanki kamatok huzamosabb ideig a nulla szint közelében rögzülnek. Ilyen esetben a monetáris politika nem semlegesíti a fiskális expanziót. Christiano és szerzőtársai (2011), Woodford (2011), valamint Erceg és Linde (2016) megmutatják, hogy likviditási csapdában változatlan nominális kamatok mellett a kiadási multiplikátor még akkor is szignifikánsan nagyobb 1-nél, ha a háztartások viselkedését nem a keynesi, hanem a permanens jövedelem elmélet írja le. Szemben Keynes statikus megközelítésével, a szóban forgó tanulmányok dinamikus modellt prezentálnak, amelyek rávilágítanak olyan, a multiplikátort növelő csatornákra, amelyek az eredeti keynesi elméletből hiányoznak: a modellek szerint a jövőbeli várt költségvetési expanzió növeli az inflá- 
ciós várakozásokat, aminek hatására csökken a reálkamatláb, ami viszont növeli a jelenbeli fogyasztást, az aggregált kereslet és így a kiadási multiplikátor nagyságát.

A fentiekben idézett tanulmányoknak a jelentőségét az adja, hogy ezek az eredmények a modern makroökonómia dinamikus sztochasztikus egyensúlyi (dynamic stochastic general equilibrium, DSGE) modelljein alapulnak. Jellemzően a válság előtti DSGE-irodalom szkeptikus volt a fiskális politika alkalmazhatóságával kapcsolatban. A fentebb idézett szerzők viszont demonstrálják, hogy likviditási csapda esetén még a sztenderd DSGE modellek is a fiskális politika hatékonyságát implikálják.

A továbbiakban olyan új eredményeket ismertetünk, amelyek szintén a modern dinamikus makroökonómia eszköztárán alapulnak, de kiterjesztik a sztenderd DGSE-modelleket. Míg a sztenderd modellekben a háztartások adósságának csak a várható életpálya-jövedelmük szab korlátot, addig a most ismertetésre kerülő tanulmányok figyelembe veszik, hogy a valóságban és főleg válságok idején az adósságkorlátok ennél jóval szigorúbbak.

Eggertsson és Krugman (2012), valamint Eggertsson és Mehrotra (2014) tanulmányai a folyó jövedelem és fogyasztás kapcsolatát vizsgálják új szemszögből: a szerzők rámutatnak arra, hogy pénzügyi válságok után, mivel az adósságkorlátok szigorúbbá válnak, a háztartások nem képesek simítani fogyasztásukat, tehát eladósodott háztartások esetén nem múködik a permanens jövedelem elmélet. Ebből adódóan egy válság utáni recesszióban megnő a folyó jövedelemnek a fogyasztásra gyakorolt hatása, vagyis az aggregált fogyasztás viselkedését jó közelítéssel írja le a keynesi fogyasztási függvény. Ez alapján a szerzők megmutatják, hogy mély recesszióban és likviditási csapdában a gazdaság viselkedése hasonlatossá válik az eredeti keynesi elméletben felvázolthoz, ezért ilyen esetben a fiskális politika hatékony, és a kiadási multiplikátor értéke nagyobb, mint 1 . Továbbá a fenti tanulmányok felhívják arra a figyelmet, hogy ha léteznek adósságkorlátos fogyasztók, akkor biztosan nem teljesül a ricardói ekvivalencia, ebből adódóan a multiplikátor nagysága növelhető, ha a kiadásokat nem adóból, hanem a deficit növelésével finanszírozzák.

Összefoglalva az eddigieket, bár a fiskális politika keynesi elméletét ért kritikák jelentős része jogos, de válságok utáni mély recessziókban mégis érvényessé válnak Keynes főbb következtetései. Ilyen esetben a gazdaság likviditási csapdába kerül, aminek következtében a monetáris politika hatástalanná válik, a költségvetési expanzió hatása viszont felerősödik részben azért, mert nem semlegesíti azt a tétlen monetáris politika, részben pedig azért, mert az eladósodott fogyasztók miatt a fogyasztás jobban együtt mozog a folyó jövedelmekkel, mint normálhelyzetben. Továbbá recesszióban a kihasználatlan kapacitások és lefelé merev bérek miatt a kínálat reakciója is döntően mennyiségi. 
A fenti érveket összevetve a keynesi elmélet kritikáinak a következtetéseivel, elmondható, hogy a makroökonómiai elmélet jelenlegi álláspontja szerint a fiskális politika hatékonysága és a kiadási multiplikátor állapotfüggő. Fellendülések idején a kiadási multiplikátor kisebb, mint 1, ezért a költségvetési politika nem hatékony, de ilyen esetekben nincs is szükség rá, a monetáris politika segítségével megfelelő mértékben lehet befolyásolni a gazdaság ciklikus helyzetét. Ezzel szemben válságok utáni mély recessziókban a kiadási multiplikátor értéke 1-nél nagyobb, tehát a fiskális politika ilyenkor hatékony eszköz a gazdaság élénkítéséhez, ráadásul ilyen esetben szükség is van rá, mert a monetáris politika hagyományos eszközei hatástalanná válnak. A fenti gondolatmenet az 5. ábra foglalja össze.

\section{5. ábra}

Válság utáni álláspont: állapotfüggő kiadási multiplikátor

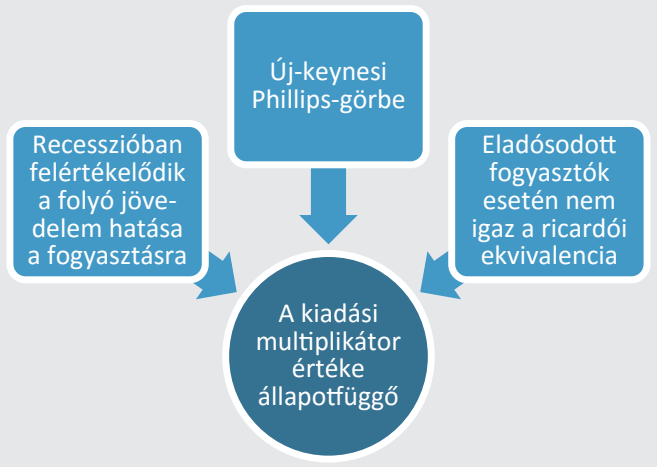

\subsection{Kis, nyitott gazdaságok}

Az eddig ismertetett elméleti keretrendszer alapvetően kevéssé nyitott és nagyméretű gazdaságok - mint például az USA - elemzésére készült. Ahhoz, hogy ezt kisméretű és nyitott gazdaságokra is alkalmazhassuk, néhány további megfontolással kell kiegészítenünk az eddigi elemzést. Egy kis, nyitott gazdaság esetén létezik két eddig nem tárgyalt fontos tényező, ami befolyásolja a multiplikátor nagyságát.

Egyrészt egy nyitott gazdaság esetén, ha a belföldi keresletnek van importigénye, akkor a költségvetési kiadások által elsődlegesen és addicionálisan generált jövedelmek egy része „elszivárog” külföldre. Ha a belföldi gazdaság elég nagyméretű, akkor a külföldön generált jövedelem képes a külföldi GDP-t érdemben növelni, ami növelheti a külföld keresletét a belföldi termékek iránt, és ez részben kompenzálhatja az elszivárgott jövedelmet. Viszont ha a gazdaság kisméretű, akkor ez a kompenzációs hatás nem létezik, mert ilyenkor a belföldről elszivárgó jövedelem nem elégséges 
ahhoz, hogy érdemben befolyásolja a külföldi konjunktúrát. Tehát egy kis nyitott gazdaság esetében a gazdaság importigénye miatt csökken a kiadási multiplikátor nagysága. Például ha az eredeti keynesi gondolatmenetet egy kis nyitott gazdaságra alkalmazzuk, akkor a kiadási multiplikátor értékét deficitfinanszírozás mellett a következő képlet határozza meg: $1 /(1-c+m)$, ahol $c$ a fogyasztási határhajlandóság, $m$ pedig az importfelhasználási határhajlandóság. Ha a gazdaság importigénye nagy, azaz $m$ értéke magas, akkor a multiplikátor értéke szignifikánsan alacsonyabb, mint zárt gazdaságok esetén.

Másrészt a multiplikátor értéke nem független az árfolyamrendszertől. A fiskális politika hatásait kis nyitott gazdaságok esetén először Fleming (1962) és Mundell (1963) elemezte. Benczes és Kutasi (2010) könyve 2. fejezetében megtalálható a Mundell-Fleming-modell formális levezetése és tárgyalása.

A Mundell-Fleming-modell szerint a fiskális expanzió fix árfolyamrendszer esetén hatékonyabban emeli a kibocsátást. A gondolatmenet a következő: ha a fiskális politika növeli a keresletet, akkor a kamatok is emelkednek, a magasabb kamat a hazai fizetőeszközre pedig felértékelődési nyomást helyez. Fix árfolyamrendszer esetén erre a jegybank beavatkozik, hogy monetáris lazítással mérsékelje (illetve megszüntesse) a felértékelődést, így végső soron a monetáris politika megtámogatja a költségvetési élénkítést. Ezzel szemben lebegő árfolyamrendszer esetén pusztán az árfolyam mozgására nem reagál a jegybank, és amennyiben nem, vagy kisebb mértékben élénkít a fix árfolyamrezsimhez képest, úgy a felértékeltebb árfolyam mérsékeli a kibocsátás növekedését a visszafogottabb exportteljesítményen keresztül, és végsősoron kisebb a fiskális impulzus növekedési hatása. Modern dinamikus sztochasztikus modellkeretben Farhi és Werning (2016) elemzi a fiskális expanzió hatásait nyílt gazdaságokban, de az alapvető következtetéseik összhangban vannak Fleming és Mundell eredményeivel.

A nagy gazdaságokra kidolgozott fiskális elméletből még egy nagyon fontos elem hiányzik, ami kis gazdaságok esetében kulcsfontosságú: a költségvetési expanzióhoz kapcsolódó deficit fenntarthatóságának a kérdése, lásd erről például Benczes és Kutasi (2010) 3. fejezetét, illetve D'Erasmo és szerzőtársai (2016) tanulmányát. Néhány nagy gazdaság esetében - mint például az USA vagy Németország - az államadósság növelésének gyakorlatilag nincsenek korlátai, még relatíve magas GDP-arányos államadósság esetében is úgy tekintenek az államadósság finanszírozására a pénzügyi piacok, mint kockázatmentes befektetésre. Ezzel éles ellentétben áll a kisméretű gazdaságok finanszírozási gyakorlata. Ezekben a gazdaságokban az államadósság növekedése hatására nő a finanszírozás kockázati felára, sőt egy bizonyos küszöbértéken túl a felár akár extrém ütemben is nőhet. Illetve előfordulhat olyan szintje is az adósságnak, amikor teljesen elapadnak a finanszírozási források. 
Mindez szignifikánsan befolyásolja a költségvetési politika hatékonyságát. Kellően magas államadósság mellett a deficitből finanszírozott fiskális expanzió olyan mértékben növelné az államadósságot és a finanszírozási terheket, ami már nem élénkíti a gazdaságot, hanem kontrakciós hatása van. Extrém magas finanszírozási terhek mellett előbb vagy utóbb a kormányzat olyan fiskális restrikcióra kényszerül, amely jelentős növekedési áldozattal jár. Az, hogy a gazdaság kontrakciója milyen gyorsan következik be, attól függ, hogy a releváns gazdasági szereplők várakozásai mennyire szofisztikáltak. De az időtávtól függetlenül, ha nem statikusan szemléljük a problémát, akkor magas államadósság mellett a költségvetési kiadások növelése végső soron nem növeli, hanem csökkenti a reál-GDP-t. ${ }^{7}$

\section{Empirikus vizsgálatok}

\subsection{Identifikálás}

A kiadási multiplikátorok empirikus mérését alapvetően nehezíti, hogy maga a multiplikátor nem közvetlenül identifikálható paraméter ${ }^{8}$. Sokkal inkább számos más tényezőtől függ az értéke, melyek között interaktív hatások állnak fenn. A fiskális multiplikátor függ az általános gazdasági helyzettől, a gazdasági szereplők várakozásaitól, a gazdaságpolitika reakciójától, tehát általában számos strukturális paramétertől, melyek pontos megmérése kihívást jelent az elemző számára. A fő probléma abban áll, hogy nem elegendő pusztán a GDP időbeli változását elosztani az ugyanebben az időszakban bekövetkezett fiskális instrumentum változásával a tényadatokat használva, hogy megtudjuk egységnyi fiskális változó értékének változása mennyit okoz a GDP-ben. Már csak azért sem, mert a gazdasági aktivitásra számos más tényező is hatással van. Az identifikáció során arra vagyunk kíváncsiak, hogy kizárólag a fiskális instrumentum hogyan befolyásolja végül a kibocsátást. A két változó között kétirányú ok-okozati kapcsolat lehetséges. Egyrészt maga a fiskális kiadás változtatása hatással van a GDP-re, ez az a csatorna, mely lényegében magát a fiskális multiplikátort identifikálja (6. ábra, 1. számú nyíl). Másfelől viszont a gazdaságpolitika is reagálhat ${ }^{9}$, sőt reagál is a GDP változásaira, például éppen a kormányzati kiadások élénkítésével, vagy éppen visszafogásával (6. ábra, 2. számú nyíl). Az ún. identifikációs probléma tehát abban áll, hogy kizárólag az első csatornát ragadjuk-e meg. Tehát az ok-okozati viszonyok közül annak a hatását keressük, amelyet a kormányzati instrumentum fejt ki a gazdasági növekedésre és nem fordítva.

\footnotetext{
${ }^{7}$ Baksa és szerzőtársai (2014) tanulmánya részletesen tárgyalja, hogy a várakozások milyen módon befolyásolják a multiplikátort. Ugyanakkor ez a modell nem vizsgálja a fiskális politika hatásait likviditási csapda esetén, ezért alacsony multiplikátor-értékeket találnak.

${ }^{8}$ Ez általában igaz a költségvetési multiplikátorok más fajtái, pl. az adó-multiplikátorok esetében is.

${ }^{9}$ Akár direkt lépésekkel, akár az automatikus stabilizátorokon keresztül. Ez utóbbit részletesebben kifejtjük a 4. Gazdaságpolitikai implikációk résznél.
} 


\section{6. ábra \\ Identifikációs probléma stilizált ábrázolása}

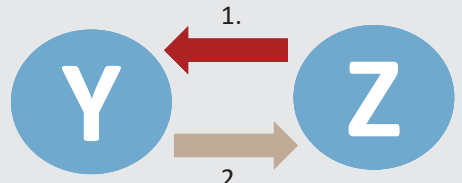

2.

Megjegyzés: Jelölések: Y a kibocsátás, Z a vizsgált fiskális instrumentum. Az 1. csatorna kizárólag a kormányzati kiadások, illetve adók változásának hatása a kibocsátásra, a 2. csatorna pedig a kormányzati reakció a GDP változására.

Ennek megoldására a szakirodalomban alapvetően két főbb, szélesebb körben elterjedt módszer létezik, melyeket a későbbiekben részletesebben kifejtünk. Az egyik megközelítés egy strukturális vektor-autoregresszív modell (SVAR) segítségével identifikálja a fiskális sokkokat, és ez alapján már meghatározhatók a multiplikátor-értékek. Ezt a módszert először Blanchard és Perotti (2002) alkalmazta fiskális multiplikátorok becslésére. Ez esetben az identifikációs megkötés jellemzően az szokott lenni, hogy a GDP változása nem befolyásolja az adott időszaki kormányzati kiadást. Ez a feltételezés nem pusztán egyszerűsítő és a SVAR-szimulációkhoz szükséges módszertani megkötés, hanem közgazdasági megfontolás alapján létrejött megközelítés. Eleve az adott időszaki GDP még nem ismert, annak pontos értéke értelemszerűen csak később, legalább a negyedév elteltét követően válik ismertté, másrészt intézményi tulajdonságok miatt a gazdaságpolitikai lépés sem föltétlenül tud azonnali lenni ${ }^{10}$.

A másik megközelítés arra épít, hogy olyan fiskális változót keres, amely vélhetően független a GDP alakulásától. Erre vonatkozóan Barro (1981), majd később Ramey és Shapiro (1998) az első példák, melyekben a szerzők a katonai kiadások segítségével identifikáltak fiskális sokkokat. Egyszerűen a tervezett katonai kiadásokról szóló bejelentésekből származó információkat használták fel sokkváltozóként. A hadi kiadások változása a hazai növekedéstől független, leginkább külső (háborús időszak) tényezőktől függ, így identifikációs szempontból megfelelő választás ennek felhasználása.

Egyéb, fiskális sokkok hatásait vizsgálandó empirikus módszerek között meg kell említeni még azt, melyben teljes ökonometriai modelleket használnak fel a szerzők. E modellek felépítésének ugyanakkor nem kizárólagos célja a fiskális impulzusok megbecslése, ugyanakkor ökonometriai felépítésükből adódóan alkalmasak ilyen szimulációk készítésére, így kiaknázhatók ezek a lehetőségek. ${ }^{11}$ Emellett egy másik megközelítés az, amikor egy új-keynesi makrogazdasági modellt használnak a szerzők, melynek legfőbb paramétereit megbecsülik, majd az így kapott paraméterek

\footnotetext{
${ }^{10}$ Például nagyobb adó vagy kiadási változtatásokat társadalmi, szakmai, parlamenti viták előznek meg a fiskális intézkedés hatásait illetően, melyekből szükségszerűen adódhat némi későbbi tényleges reakció.

${ }^{11}$ Lásd pl.: Horváth et al. (2006)
} 
felhasználásával szimulációk alapján számítható a fiskális multiplikátor. ${ }^{12}$ Ez utóbbi gyakorlat empirikus erősségét alapvetően az csökkenti - a bayesi becslés komplex modellekre jellemző szokásos becslési tulajdonságain túl - hogy a felhasznált modellek önmagukban erős elméleti restrikciókat eredményeznek, így jóval kevesebb teret engednek maguknak a megfigyelt tényadatokból származó információknak.

A módszerek részletesebb kifejtését és számos módszertani, szakirodalmi hivatkozást kiválóan foglal össze Chinn (2013), valamint Spilimbergo és szerzőtársai (2009). A továbbiakban mi most leginkább az első két módszerre koncentrálunk, illetve olyan vizsgálatokra, ahol kifejezetten a fiskális multiplikátorok értékét befolyásoló tényezőket elemezték a szerzők.

\subsection{Eredmények - az irodalom áttekintése}

A kormányzati kiadások multiplikatív hatásairól részletes elemzést készít Ilzetzki és szerzőtársai (2011) tanulmánya, melyben több mint negyven országot vizsgáltak az 1960-2007 közötti időszakban. Főként arra keresték a válaszokat, hogy a legfontosabb gazdasági tulajdonságok hogyan befolyásolják a fiskális stimulus hatását. A multiplikátor értékét meghatározó tényezők közül a szerzők az alábbiakat vizsgálták: a fejlettség (fejlett vagy feltörekvő), az árfolyamrendszer különbsége (fix vagy rugalmas), a gazdaság nyitottsága, valamint az eladósodottság mértéke.

A becslésüket panel SVAR-modellel készítették, azzal a strukturális megkötéssel, hogy a kormányzati fogyasztásra az adott negyedéves GDP nincs hatással, csak egy negyedévvel később ${ }^{13}$. Egyaránt vizsgálták az azonnali és a hosszú távú hatásokat, valamint hogy szignifikáns-e a különbség a kormányzati fogyasztás, illetve a kormányzati beruházás multiplikátorai között. Eredményeiket a következő táblázatban foglaltuk össze.

\section{1. táblázat}

Fiskális kiadási multiplikátorok értékei

\begin{tabular}{l|c|c|c|c} 
& \multicolumn{2}{|c|}{ Azonnali multiplikátor } & \multicolumn{2}{c}{ Hosszú távú multiplikátor } \\
\cline { 2 - 5 } & $\begin{array}{c}\text { Kormányzati } \\
\text { fogyasztás }\end{array}$ & $\begin{array}{c}\text { Kormányzati } \\
\text { beruházás }\end{array}$ & $\begin{array}{c}\text { Kormányzati } \\
\text { fogyasztás }\end{array}$ & $\begin{array}{c}\text { Kormányzati } \\
\text { beruházás }\end{array}$ \\
\hline Fejlett gazdaságok & 0,37 & 0,41 & 0,8 & 1,15 \\
\hline Fejlődő gazdaságok & $-0,21$ & 0,57 & 0,18 & 0,75 \\
\hline Fix árfolyam & 0,09 & 0,36 & 1,5 & 1,42 \\
\hline Rugalmas árfolyam & $-0,28$ & 0,46 & $-0,41$ & 0,16 \\
\hline Zárt gazdaság & 0,02 & 0,46 & 1,29 & 0,7 \\
\hline Nyitott gazdaság & $-0,28$ & 0,51 & $-0,75$ & $-0,23$ \\
\hline
\end{tabular}

Forrás: Ilzetzki és szerzőtársai (2011)

12 Lásd pl.: Zubairy (2010)

${ }^{13}$ A SVAR-modellben a következő endogén változók szerepeltek: kormányzati instrumentum (pl. kormányzati fogyasztás), jegybanki alapkamat, GDP, folyó fizetési mérleg, reálárfolyam. A becslések során egységesen 4 késleltetést használtak. Különböző késleltetések érdemben nem befolyásolták a következtetéseiket. 
Általában megállapítják, hogy a kormányzati beruházások multiplikátora magasabb, mint a kormányzati fogyasztásé, ugyanakkor számos esetben statisztikailag nincs szignifikáns különbség a kettő között. A gazdaságok fejlettsége alapján a fejlett gazdaságok esetében jóval magasabb a multiplikátor. A feltörekvő gazdaságoknál nem is különbözik szignifikánsan nullától a kormányzati fogyasztás hosszú távú keresletélénkítő hatása, ugyanakkor a kormányzati beruházásé pozitív, és érdemben magasabb. A fejlődő gazdaságokra hasonlóan alacsonyabb multiplikátorértékeket becsül Estevão - Samake (2013) és Kraay (2012) is.

A különböző árfolyamrendszerek vizsgálat esetére azt találták, hogy a fiskális multiplikátor értéke nagyobb fix árfolyam rezsim esetén, rugalmas árfolyamrendszerhez képest. Hasonló következtetésre jut Born et al. (2013), ők fix árfolyamrendszer esetén közel 2-3-szor nagyobb azonnali multiplikátorhatást mértek rugalmas árfolyamrendszerhez képest. E mögött az az intuíció áll, hogy fiskális sokk esetén a rugalmas árfolyamrendszerben gyorsabban tudnak érvényesülni olyan mechanizmusok, amelyek gazdasági alkalmazkodást indítanak el.

A gazdaságok nyitottságát vizsgálva zárt gazdaságokra általában magasabb fiskális multiplikátort találnak a szerzők, összhangban a korábban említett Flemming (1962) és Mundell (1963) eredményeivel.

Ilzetzki és szerzőtársai (2011) tanulmánya 2007-ig, tehát a válságot megelőző időszakig tartó mintát használ, és alapvetően a költségvetési politikával szembeni szkeptikus álláspontot támasztja alá. Ettől jelentősen eltérő eredményekre jutottak azok a vizsgálatok, amelyek a válság utáni időszakot is figyelembe vették a becsléseknél.

Ezek közül a legnagyobb feltúnést Blanchard és Leigh (2013), az IMF kutatóinak a tanulmánya keltette, akik arra a következtetésre jutottak, hogy a fiskális multiplikátor értéke a válságot követően 1-nél több, jóval nagyobb, mint azt korábban gondolták. A tanulmány nem kis vihart kavart megjelenésekor, hiszen az IMF gondolkozása addig inkább a szkeptikus állásponthoz volt közel. Becslésük során a következő megfontolásokat követték. A következő egyenletet becsülték:

\section{forecast error of growth $=\alpha+\beta \cdot$ forecast of fiscal consolidation $+\epsilon$}

Az egyenletben az egyik évről a másik évre vonatkozó GDP-növekedésre vonatkozó előrejelzés hibáját regresszálták a fiskális konszolidáció változására vonatkozó várakozással. A jobb oldalon a kormányzat strukturális egyenlege szerepel. Racionális várakozások mellett, és feltéve, hogy előrejelzéseknél a megfelelő modellt használták, $\beta$ értékének nullának kell lennie. Vizsgálatukat a 2010-2011-es időszakra végezték el 26 országra ${ }^{14}$. A becslésük $\beta$ értékére szignifikánsan negativ értéket eredményezett.

\footnotetext{
${ }^{14}$ Alapvetően EU27, de Észtország, Lettország, Litvánia és Luxemburg esetében nem volt adat a 2010 áprilisi WEO-ban strukturális fiskális egyenlegre. Ugyanakkor 3 fejlett európai gazdasággal - Izland, Norvégia, Svájc - bővítették a mintát, így összesen 26 országra (27-4+3) vizsgálódtak.
} 
Nagyon sok robusztussági vizsgálatot végeztek, különféle specifikációkkal, és bár számos esetben eltérő eredmények adódtak, összességében szignifikánsan negatív értékeket becsültek a paraméterre. Például bizonyos országokat kihagytak a becslésből, a kiugró értékeket különböző statisztikai eljárásokkal kezelték, fenti egyenletet különböző plusz magyarázóváltozókkal bővítették (pl. CDS, fiskális egyenleg, kezdeti adósság, háztartások adóssága, folyó fizetési mérleg egyenlege, tervezett fiskális lépések helyett tényleges fiskális intézkedés), emellett bővítették a mintát 2009-2012 időszakra. Továbbá a válság előtti időszakra (1997-2008) is elvégezték a becslést, melyre szignifikánsan nulla értéket kaptak $\beta$-ra.

Az eredmények tehát robusztusak voltak a különböző specifikációkra, így azok arról árulkodtak, hogy a jelenlegi fiskális multiplikátorértékek nagyobbak, mint azt korábban gondolták. Bár annak meghatározása, hogy pontosan mekkora multiplikátorértékekkel készültek a korábbi előrejelzések, nem egyértelmű, hiszen az alapvetően a fiskális konszolidáció szerkezetétől, illetve a gazdasági kondícióktól függ, de általános vélekedés volt számos tanulmány eredménye alapján, hogy a fejlett gazdaságok vonatkozásában 0,5 körüli a multiplikátor két év alatt. Például az IMF (2008) fiskális politikai fejezetében 21 fejlett gazdaságra 0,5-ös multiplikátorértéket becsültek az 1970-2007 közötti időszakra, valamint az IMF (2010) 15 fejlett gazdaságra 1979-2009-re átlagosan szintén 0,5 körüli értéket becsült. A szerzők mindezek fényében megállapítják, hogy becslési eredményeik alapján jelenleg 1 fölötti a multiplikátor értéke. Ugyanakkor megjegyzik, hogy az eredményeket óvatosan kell kezelni, már csak azért is, mert alapvetően nincs egyetlen és kizárólagos multiplikátorérték minden gazdaságra, minden fiskális sokkra. A multiplikátor értéke országonként és időszakonként eltérő lehet, továbbá, ahogy a gazdaságok kilábalnak a válságból, a multiplikátorértékeik is vélhetően visszatérnek a válság előtti értékekhez.

Az imént vázolt módszert alkalmazva Mohlmann és Suyker (2015) a későbbi időszakokra is elvégezte a becslést. Egyrészt frissítették: a Blanchard és Leigh (2013) által használt adatbázis 3 évvel későbbi frissített verzióját használták. A 2009-2010es, valamint a 2010-2011 közötti időszakra ők is hasonlóan szignifikánsan negatív béta értéket találtak, ellenben 2011-2012-re már nem szignifikáns az együttható. A későbbi évekre pedig nullához közelit becsültek. ${ }^{15}$

Az eddig áttekintett empirikus eredmények alapján megfogalmazható a sejtés, hogy a kiadási multiplikátor értéke nem állandó, a gazdasági ciklus állapotától függ. Mindezt egyértelműen alátámasztják Auerbach és Gorodnichenko $(2012,2013)$ tanulmányai. A szerzők egy rezsimváltós modell becslésével recessziós környezetre 1,0-1,5 körüli, míg expanzív időszakra 0,0-0,5 körüli fiskális multiplikátorértékeket becsülnek.

\footnotetext{
${ }^{15}$ A szerzők megjegyzik, hogy ez az eredmény persze azt is tükrözheti, hogy az IMF-előrejelzők „,tanultak” a válságból, és a jelzett későbbi időszakokra már a válság előtti időszakhoz képest nagyobb multiplikátorokkal számoltak.
} 
Fő megállapításuk szerint tehát a fiskális expanzió sokkal hatékonyabb recessziós időszakban, mint expanzió idején. ${ }^{16}$ Az eredményeiket a 7. ábra foglalja össze.

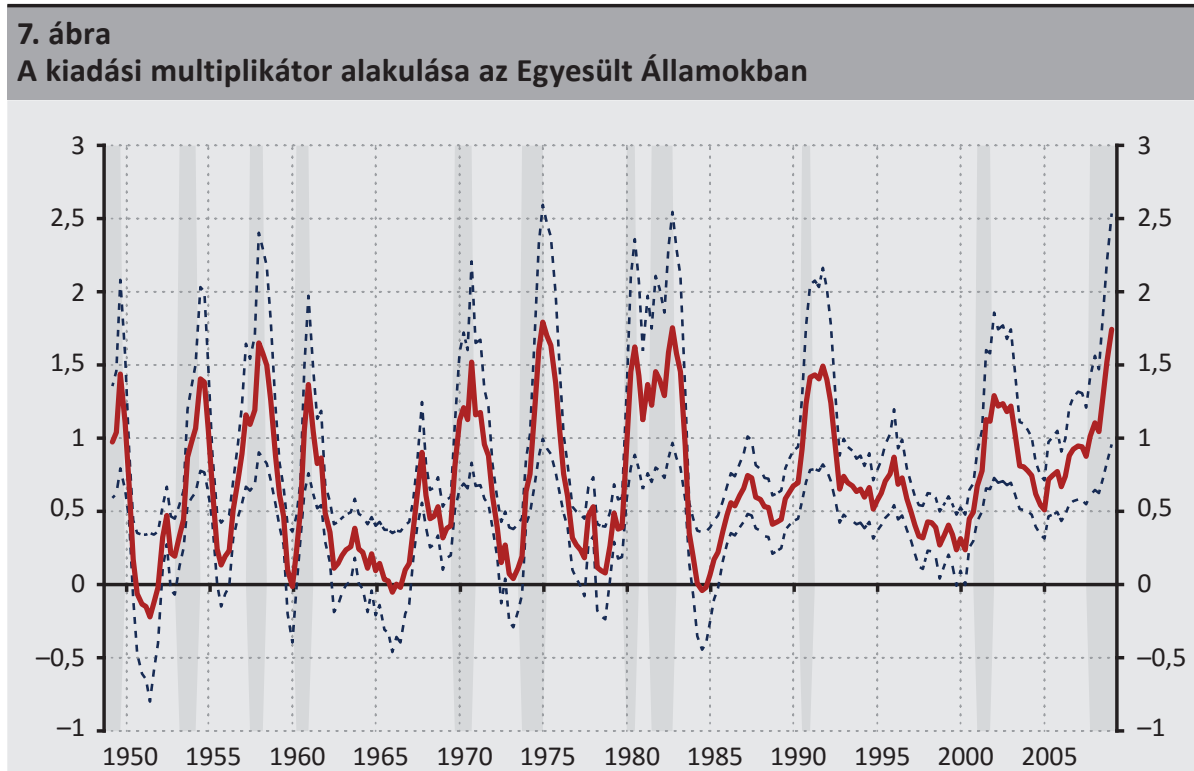

Megjegyzés: A szürke oszlopok az NBER módszertan alapján beazonosított recessziókat reprezentálják. A kék szaggatott vonalak a 90 százalékos konfidencia intervallumot jelölik.

Forrás: Auerbach - Gorodnichenko (2012)

A fenti eredményeket megerősíti Huidrom és szerzőtársai (2016) tanulmánya, megmutatva, hogy recessziós időszakban jóval magasabb a fiskális élénkítés gazdaságösztönző hatása. Míg recessziós időszakban 1,5-2 körüli multiplikátorok adódnak 1-2 éves horizontra, addig az expanziós időszakokra becsült értékek statisztikailag tipikusan nem különböznek a nullától.

A fiskális multiplikátor értékét ugyanakkor nem pusztán a reálgazdaság ciklikus helyzete befolyásolja érdemben, hanem az adott ország eladósodottsági szintje is hatással lehet rá. Ilzetzki és szerzőtársai (2011) tanulmánya szerint a kormányzati élénkítési politika szerepét érdemben befolyásolja az adott gazdaság adósságszintje. A túlzott eladósodottság érdemben fékezi a fiskális expanzió növekedési hatását. GDP-arányosan több mint 60 százalékos adósságszinttel rendelkező gazdaságok esetében negatív fiskális multiplikátor adódik, mely erős jelzés és egyúttal komoly kihívás a túlzottan eladósodott gazdaságok válságokból való kilábalására vonatkozóan. Robusztussági vizsgálatukkal azt találták a szerzők, hogy nagyjából 60 százalékos

\footnotetext{
${ }^{16}$ A különböző fiskális kiadásokat is megvizsgálták, tipikusan a hadi kiadásokra, illetve a kormányzati beruházásokra kaptak magasabb multiplikátorértékeket, szemben a kormányzati fogyasztás keresletélénkítő kisebb hatásával.
} 
küszöbszámnál nagyobb eladósodottság eredményez inszignifikáns multiplikátort. Huidrom és szerzőtársai (2016) is hasonló eredményre jutottak. A szerzők 34 (köztük 19 fejlett, 15 feltörekvő) országot vizsgálnak az 1980Q1-2014Q1 közötti időszakra, ún. IPVAR ${ }^{17}$-modell segítségével. Az azonnali hatás vonatkozásában nagyjából 65-70 százalékos eladósodottsági szinttől válik inszignifikánssá a fiskális multiplikátor, alacsony adósságszint esetén pedig a hosszú távú érték közel van 1-hez.

\section{Gazdaságpolitikai implikációk}

Ebben a szakaszban áttekintjük, hogy az elmélet és az empirikus vizsgálatok alapján milyen következtetéseket lehet levonni a költségvetési politika múködtetésére vonatkozóan. A célunk nem az, hogy egy szigorú értelemben vett optimális fiskális politikai szabályt írjunk le, hanem számba vesszük azokat az alapelveket, amelyek véleményünk szerint a helyes fiskális politika jellemzői.

Amint azt az előző szakaszokban demonstráltuk, mind az elméleti modellek, mind az empirikus vizsgálatok alátámasztják, hogy a fiskális kiadási multiplikátorérték nagysága állapotfüggő: fellendülések idején relatíve alacsony, míg recessziókban, különösen nagy válságok után relatíve magas, 1-nél nagyobb.

Ebből az következik, hogy a helyes költségvetési politika is állapotfüggő. Nem célszerú és nem is lehetséges a gazdaságot minden helyzetben fiskálisan élénkíteni, ugyanakkor az sem igaz, hogy mindig, minden körülmények között szigorú költségvetési politikára van szükség.

Gyakori érv a fiskális politikával szemben, hogy jóval nehézkesebb implementálni, mint a monetáris politikát, ezért nem érdemes a konjunktúraciklusok simítására használni. ${ }^{18}$ A 2007-2008-as válság után azonban bebizonyosodott, hogy egy mély recesszióban a monetáris politika gyorsan beleütközik a korlátaiba, és hatástalanná válik. Ilyen esetben pedig a gazdaság élénkítésének egyetlen eszköze a fiskális expanzió, aminek alkalmazása nélkül a gazdaság könnyen a tartós stagnálás állapotába kerülhet, amint azt Eggertson és Mehrotra (2014) modellje demonstrálja. Ráadásul az ilyen helyzetben a legnagyobb a fiskális multiplikátor, tehát nemcsak kívánatos, hanem hatékonyan alkalmazható is a költségvetési politika.

Ugyanakkor a deficit fenntarthatósága szempontjából az irodalom hagyományosan szkeptikus a fiskális élénkítéssel szemben, úgy vélik, hogy még a kiadási multiplikátor magas értéke mellett is lehetetlen érdemi gazdaság élénkítést végrehajtani, ugyanis ez viszonylag hamar a deficit fenntarthatatlanságához vezet, erre vonatkozó számításokat közöl például Chand (1993) tanulmánya.

\footnotetext{
${ }^{17}$ Interacted Panel Vector Autoregressive model.

${ }^{18}$ Természetesen itt az olyan mértékű konjunktúraingadozásokra gondolunk, amelyek kezelésére nem elégségesek az automatikus stabilizátorok.
} 
Ezzel szemben a válság utáni kutatások azt támasztják alá, hogy a válságokban végrehajtott fiskális expanzió nem feltétlenül vezet kezelhetetlen méretú deficithez. Delong és Summers (2012) megmutatja, hogy ha a recesszió olyan mély, hogy hosszú távú negatív növekedési hatásai vannak - azaz hiszterézis esetén - reális paraméterértékek mellett a fiskális expanzió akár önfinanszírozó is lehet, azaz a hosszú távú növekedési nyereségből adódó többlet-adóbevétel fedezetet nyújthat az expanziót finanszírozó deficitre. Auerbach és Gorodichenko (2017) empirikus tanulmánya öszszhangban van a fenti eredményekkel, a fejlett gazdaságokra irányuló vizsgálatuk szerint a válságok idején végrehajtott fiskális élénkítések nem vezettek a GDP-arányos adósság, illetve a kockázati mérőszámok permanens növekedéséhez.

Összességében mindez nem jelenti azt, hogy kis nyitott, eleve eladósodott országokban a fiskális élénkítésen alapuló válságkezelés feltétlenül járható út, de a legutóbbi válság éppen azt bizonyítja, hogy a költségvetési restrikció sem feltétlenül működik ilyen esetekben. Hiszen, ha a multiplikátor értéke magas, a fiskális kiadások egységnyi csökkentése várhatóan egységnyinél nagyobb mértékben csökkenti a GDP-t, aminek eredményeként a GDP-arányos adósság nem csökken, hanem nő. Ezért a restrikció éppen az eredeti céljával ellentétes eredményt ér el. Hasonló történet játszódott le Görögországban a válság után.

Tehát ha egy gazdaság úgy kerül mély válságba és likviditási csapdába, hogy nincs fiskális mozgástere, akkor olyan csapdába kerül, amiből önerőből nehéz kikerülni. A fiskális lazítás nem lehetséges, de a szigorítás sem oldja meg helyzetet. Blanchard és szerzőtársai (2016) egy szofisztikált DSGE-modell segítségével vizsgálják ezt a problémát az euroövezet központi és perifériaországai esetében. A szerzők számításai szerint ilyen esetben a központi országok fiskális expanziója segíthet a perifériaországokon. Ugyanis a központ költségvetési kiadásainak egységnyi növelése egységnyinél nagyobb mértékben növeli a perifériaországok reál-GDP-jét.

Mivel a fiskális mozgástér hiánya mély recesszióban és likviditási csapdában rendkívül megnehezíti a válságból való kilábalást, nagyon fontos, hogy fellendülések idején felépítsék a fiskális mozgásteret. Azaz fellendülések idején érdemes szigorú fiskális politikát folytatni. Egyrészt ilyenkor nincs szükség fiskális élénkítésre, a ciklusok simításának az elvével éppen ellentétes a gazdaság túlfútöttségét növelni. Másrészt ekkor alacsony a fiskális multiplikátor, tehát a kiadások növelése nem élénkítené számottevően a gazdaságot, a csökkentése viszont nem járna számottevő kibocsátási veszteséggel. De a legfontosabb szempont az, hogy fellendülések idején szigorú fiskális politikával fel lehet építeni azt a fiskális mozgásteret, amire egy esetleges válság esetén nagy szükség van.

Az eddigiek alapján elmondható, hogy anticiklikus költségvetési politikát érdemes folytatni. Azonban az anticiklikus politika hatékony alkalmazása nagy körültekintést igényel. Fontos a gazdaság ciklikus pozíciójának minél robusztusabb becslése, vagy 
a kiadási multiplikátor aktuális értékének a körültekintő megbecslése. Az anticiklikus költségvetési politika implementálását nagymértékben segítheti az automatikus stabilizátorok alkalmazása. Automatikus stabilizátornak azt nevezzük, amikor a költségvetési egyenleg automatikusan megváltozik akkor, ha a gazdasági konjunktúra új fázisba lép. Például recesszió esetén a kiadások stabil pályán növekednek, miközben a bevételek elmaradnak a csökkenő adóalapok miatt. Az automatikus stabilizátorok előnye, hogy késlekedés nélküli, szimmetrikus költségvetési választ adnak a gazdasági ciklus változására, a cikluson átívelve pedig nem befolyásolják a költségvetés fenntarthatóságát. ${ }^{19} \mathrm{Az}$ automatikus stabilizátorok alkalmazása nem zárja ki diszkrecionális lépések használatát, például mély és tartós recessziókban szükség lehet egyedi gazdaságélénkítő költségvetési programokra is.

Érdemes hangsúlyozni, hogy az anticiklikus költségvetési politika alkalmazásának a lehetősége független attól, hogy egy adott gazdaságban átlagosan mekkora a költségvetés súlya. ${ }^{20} \mathrm{~A}$ fejlett gazdaságok esetén különböző működőképes modellek léteznek, pl. az Egyesült Államokban relatíve alacsony, Svédországban relatíve magas a költségvetés átlagos aránya a GDP-hez képest. Elvileg mindkét esetben lehetséges anticiklikus fiskális politikát folytatni, ebből a szempontból a költségvetés ciklikus pozíciója a fontos, nem az átlagos súlya. A költségvetés átlagos nagysága a fiskális mozgásteret sem feltétlenül befolyásolja. Ha magas a költségvetés súlya, de ezzel együtt az adóterhek is arányosan magasak, akkor az államadósság is kezelhető nagyságú marad, és nem korlátozza a fiskális mozgásteret.

Végezetül szeretnénk felhívni a figyelmet arra, hogy az anticiklikus költségvetési politika elve önmagában nem új eredmény, már a válság előtt ismert volt. Az újdonság az, hogy a válság óta mind az elmélet, mind az empirikus kutatások alátámasztják, hogy a fiskális multiplikátor nagysága függ a gazdaság ciklikus pozíciójától, ezáltal még határozottabban lehet az anticiklikus költségvetési politika mellett érvelni.

\section{Következtetések}

A tanulmányban azt vizsgáltuk, hogy a költségvetési politika mennyire hatékony eszköze a gazdasági ciklusok simításának. A jelenlegi közgazdasági elmélet és a legújabb empirikus kutatások szerint a fiskális politika hatékonysága és az azt mérő kiadási multiplikátor értéke állapotfüggő. Recessziók, különösen a pénzügyi válságokat követő elhúzódó és mély recessziók idején, amikor a monetáris politika hatástalanná válik, a kiadási multiplikátor értéke magas. Ezzel szemben gazdasági fellendülések idején a kiadási multiplikátor értéke alacsony. A kiadási multiplikátor nagyságát a gazdaság ciklikus pozíciója mellett a gazdaság szerkezete is befolyásolja, például

\footnotetext{
${ }^{19}$ Amint azt Buti és Gaspar (2015) tanulmánya kifejti, az automatikus stabilizátoroknak eredetileg elsősorban redisztribúciós célja volt, konjunktúrasimító hatásuk csak egy pozitív melléktermék. Éppen ezért az automatikus stabilizátorok kérdését érdemes újragondolni és konjunktúrasimító képességüket javítani.

${ }^{20}$ Ez ugyan hatással van az automatikus stabilizátorok nagyságára, de független a diszkrecionálisan hozható döntések mértékétől.
} 
kis nyitott gazdaságok esetén a multiplikátor értéke kisebb, mint a hasonló, zárt gazdaságok esetén.

Mivel a kiadási multiplikátor nagysága állapotfüggő, a költségvetési politikát érdemes anticiklikusan múködtetni. Recessziók idején, különösen, ha a monetáris politika hatástalan, fiskális expanzióval úgy lehet élénkíteni a gazdaságot, hogy az nem szorít ki fogyasztást vagy magánberuházást. Ezzel szemben fellendülések idején szigorú költségvetési politikával érdemes felépíteni azt a fiskális mozgásteret, amely válságok esetén lehetőséget ad a szükséges költségvetési expanzióra.

\section{Felhasznált irodalom}

Auerbach, A.J. - Gorodnichenko, Y. (2012). Measuring the Output Responses to Fiscal Policy. American Economic Journal: Economic Policy, 4(2): 1-27. https://doi.org/10.1257/pol.4.2.1

Auerbach, A.J. - Gorodnichenko, Y. (2013): Fiscal Multipliers in Recessions and Expansions. In: Alesina, A. - Gavani, F. (ed.): Fiscal policy after the financial crisis, University of Chicago Press.

Auerbach, A.J., - Gorodnichenko, Y. (2017): Fiscal Stimulus and Fiscal Sustainability, Kansas City Fed.

Baksa Dániel - Benk Szilárd - Jakab Zoltán (2014): Létezik „a” költségvetési multiplikátor? Fiskális és monetáris reakciók, hitelesség és költségvetési multiplikátorok Magyarországon. Szigma, 45(1-2): 57-83.

Barro, R.J. (1974): Are government bonds net wealth? Journal of Political Economy, 82(6): 1095-1117. https://doi.org/10.1086/260266

Barro, R.J. (1981): Output effects of government purchases, Journal of Political Economy, 89: 1086-1121. https://doi.org/10.1086/261024

Batini, N. - Eyraud, L. - Forni, L. - Weber, A. (2014): Fiscal Multipliers: Size, Determinants, and Use in Macroeconomic Projections. Fiscal Affairs Department, IMF, Technical Notes and Manuals, September 2014.

Benczes István - Kutasi Gábor (2010): Költségvetési pénzügyek. Akadémiai Kiadó.

Blanchard, O. - Perotti, R. (2002): An Empirical Characterization of The Dynamic Effects of Changes in Government Spending and Taxes on Output. The Quarterly Journal of Economics, November.

Blanchard, O. - Leigh, D. (2013): Are We Underestimating Short-term Fiscal Multipliers? American Economic Review. 
Blanchard, O. - Cerutti, E. - Summers, L. (2014): Inflation and Activity - Two Explorations, and Their Monetary Policy Implications. ECB Forum on Central Banking 2014.

Blanchard, O. - Erceg, C.J. - Linde, J. (2016): Jump-Starting the Euro Area Recovery: Would a Rise in Core Fiscal Spending Help the Periphery? Kézirat.

Born, B. - Jüßen, F. - Müller, G.J. (2013): Exchange rate regimes and fiscal multipliers. Journal of Economic Dynamics \& Control, 37: 446-465. https://doi.org/10.1016/j.jedc.2012.09.014

Buti, M. - Gaspar, V. (2015): Designing Fiscal Policy for Steady Enduring Growth, http:// voxeu.org/article/fiscal-policy-enduring-growth

Calvo, G. (1983): Staggered Prices in a Utility Maximizing Framework. Journal of Monetary Economics, 12(3): 383-398. https://doi.org/10.1016/0304-3932(83)90060-0

Chand, S.K. (1993): Fiscal Impulse Measures and Their Fiscal Impact. In: Bléjer, M.I. - Cheasty, A. (ed.): How to Measure Fiscal Deficit, International Monetary Fund.

Chinn, M. (2013): Fiscal Multipliers. The New Palgrave, Dictionary of Economics. https://doi. org/10.1057/978-1-349-95121-5_2859-1

Christiano, L. - Eichenbaum, M. - Rebelo, S. (2011): When Is the Government Spending Multiplier Large? Journal of Political Economy, 119(1): 78-121. https://doi. org/10.1086/659312

Delong, J.B. - Summers, L.H. (2012): Fiscal Policy in a Depressed Economy. Brooking Papers on Economic Activity, Spring: 2332-2374. https://doi.org/10.1353/eca.2012.0000

D’Erasmo, P. - Mendoza, E.G. - Zhang, J. (2016): What is a Sustainable Public Debt? In: Taylor, J. B. - Uhlig, H. (ed.): Handbook of Macroeconomics, Volume 2, Chapter 32: 2417-2492.

Eggertsson, G.B. - Krugman, P. (2012): Debt, Deleveraging and the Liquidity Trap: a FisherMinsky-Koo Approach. Quarterly Journal of Economics, 127(3): 1469-1513. https://doi. org/10.1093/qje/qjs023

Eggertsson, G.B. - Mehrota, N.R. (2014): A Model of Secular Stagnation, NBER WP, 20574.

Erceg, C. - Linde, J. (2012): Is There a Fiscal Free Lunch in a Liquidity Trap? International Finance Discussion Papers, 1003, Board of Governors of the Federal Reserve System.

Estevão, M. - Samake, I. (2013): The Economic Effects of Fiscal Consolidation with Debt Feedback. IMF Working Paper 13/136. https://doi.org/10.5089/9781484304488.001

Farhi, E. - Werning, I. (2016): Fiscal Multipliers: Liquidity Traps and Currency Unions. In: Taylor, J. B. - Uhlig, H. (ed.): Handbook of Macroeconomics, Volume 2, Chapter 31: 24172492. 
Friedman, M. (1957): A Theory of the Consumption Function. Princeton University Press.

Galí, J. (2008): Monetary Policy, Inflation and the Business Cycle, Princeton University Press.

Horváth Ágnes - Jakab M. Zoltán - P. Kiss Gábor - Párkányi Balázs (2006): Myths and Maths: Macroeconomic Effects of Fiscal Adjustments in Hungary. Magyar Nemzeti Bank Occasional Papers, OP 52.

Huidnrom, R. - Kose, M.A. - Lim, J.J - Ohnsorge, F.L. (2016): Under The Cloud Of Cycles: Linkages Between Fiscal Multipliers And Positions. Policy Research Working Paper, Wps7724, World Bank Group.

Ilzetzki, E. - Mendoza, E.G. - Végh, C.A. (2011): How Big (Small?) are Fiscal Multipliers? IMF Working Paper.

Keynes, J.M. (1936): The General Theory of Employment, Interest, and Money, New York: Macmillan.

Kraay, A. (2012): How Large is the Government Spending Multiplier? Evidence from World Bank Lending, The World Bank.

Lucas, R.E. (1979): Some International Evidence on Output-Inflation Trade-offs. American Economic Review, 63(3): 326-334.

Marcus, F.J. (1962): Domestic financial policies under fixed and floating exchange rates. IMF Staff Papers. 9: 369-379.

Modigliani, F. (1966): The Life Cycle Hypothesis of Saving, the Demand for Wealth and the Supply of Capital. Social Research, 33(2): 160-217.

Mohlmann, J. - Suyker, W. (2015): An update of Blanchard's and Leigh's estimates in 'Growth Forecast Errors and Fiscal Multipliers'. VOX, CEPR's Policy Portal, 01 December 2015.

Mundell, R.A. (1963): Capital mobility and stabilization policy under fixed and flexible exchange rates. Canadian Journal of Economic and Political Science, 29(4): 475-485. https:// doi.org/10.2307/139336

Owyang, M.T. - Ramey, V.A. - Zubairy, S. (2013): Are Government Spending Multipliers Greater During Periods of Slack? Evidence from 20th Century Historical Data. Federal Reserve Bank of St. Louis, Research Division, Working Paper 2013-004A.

Ramey, V. A. - Shapiro, M.D. (1998): Costly capital reallocation and the effects of government spending. Carnegie-Rochester Conference Series on Public Policy, 48(1): 145-194. https:// doi.org/10.1016/S0167-2231(98)00020-7

Ramey, V. A. (2011): Identifying Government Spending Shocks: It's All in the Timing. Quarterly Journal of Economics, 126 (1): 1-50. https://doi.org/10.1093/qje/qjq008 
Riera-Crichton, D. - Vegh, C.A. - Vuletin, G. (2016): Tax multipliers: Pitfalls in measurement and identification. Journal of Monetary Economics, 79: 30-48. https://doi.org/10.1016/j. jmoneco.2016.03.003

Sargent, T. - Wallace, N. (1975): Rational Expectations, the Optimal Monetary Instrument, and the Optimal Money Supply Rule. Journal of Political Economy, 83(2): 241-254. https:// doi.org/10.1086/260321

Spilimbergo, A. - Symansky, S. - Schindler, M. (2011): Fiscal Multipliers. IMF Staff Position Note, SPN/09/11.

Szentmihályi Szabolcs - Világi Balázs (2015): A Phillips-görbe - elmélettörténet és empirikus összefüggések. Hitelintézeti Szemle, 14(4): 5-28.

Woodford, M. (2011): Simple Analytics of the Government Expenditure Multiplier. American Economic Journal: Macroeconomics, 3: 1-35. https://doi.org/10.1257/mac.3.1.1

Zubairy, S. (2010): On Fiscal Multipliers: Estimates from a Medium Scale DSGE Model. Bank of Canada Working Paper 2010-30, November 2010. 